\title{
INTEGRATED VULNERABILITY ANALYSIS \\ FOR DISASTERS RISK REDUCTION
}

DOI: http://dx.doi.org/10.18509/GBP.2016.22

UDC: 504.4:35.077-047.44(497.2)

\author{
Assoc. Prof. Dr. Daniela Zlatunova \\ Dr. Panka Babukova \\ Sofia University 'St. Kliment Ohridski', Bulgaria
}

\begin{abstract}
Vulnerability is a key element in the risk conception (risk = hazard + vulnerability), representing the circumstances determined by 'physical, social, economic, and ecologic factors or processes, of a community, system or asset that make it susceptible to the damaging effects of a hazard' [11]. A crucial part of the policies for disaster risk reduction is the reduction of vulnerability, which is related to the susceptibility of human development: human life, economy, social organisation, and the physical aspects of the environment. Although public and economic vulnerability are perceived as the most important components of vulnerability, it is very important to take into account the significance of the biophysical basis for human life - the environmental and physical aspects of vulnerability and to deal with them in an integrated way.

The publication aims at analysis of the integrated vulnerability as a tool for disaster risk reduction by reduction of the vulnerability itself. The publication presents the approaches for integrated vulnerability analysis. The vulnerability is integrally analysed by its factors (exposure, susceptibility and resilience) and dimensions (social, economic, environmental and physical). The integrated vulnerability of a territory is measured as a combination of the factors listed above. All of them can be represented by a set of indicators, whose selection should be reasonable and well-grounded. The set of indicators should allow measurement of the vulnerability factors for each of the vulnerability dimensions. An integrated vulnerability analysis is developed and presented for a case study from Republic of Bulgaria.
\end{abstract}

Key words: integrated vulnerability analysis, disaster risk reduction, Republic of Bulgaria

\section{INTRODUCTION}

Natural hazards are nothing new to humanity. Floods, droughts, earthquakes, and others have accompanied human development from its beginning. That is why disaster risk reduction and enhancement of social sustainability remain key challenges for both developing and developed countries. The main reason for that is the growing exposure of humans and their assets in risk areas on the one hand, and on the other, the increased frequency of extreme natural events due to climate change.

Scientists agree that the reduction of the natural hazards and threats to human security cannot be achieved by putting efforts solely in natural hazards mitigation. Societies have to continue living with the changing environment, thus they need to enhance sustainability by reduction of their vulnerability to natural hazards as well. The first step in this process is to measure vulnerability at different territorial levels and its spatial and temporal 
characteristics. Therefore, the aim of the current publication is to present an overall approach for measurement of integrated vulnerability at different administrative territorial levels as a tool for disaster risk reduction in Bulgaria.

Vulnerability is a key element of the risk conception (risk = hazard + vulnerability), representing the circumstances determined by 'physical, social, economic, and ecologic factors or processes, of a community, system or asset that make it susceptible to the damaging effects of a hazard' [11] UN-ISDR. A crucial part of the policies for disaster risk reduction is the reduction of vulnerability, which is related to the susceptibility of human development: human life, economy, social organisation, and the physical environmental aspects. Although public and economic vulnerability are perceived as the most important components of vulnerability, it is very important to take into account the significance of the biophysical basis for human life - the environmental and physical aspects of vulnerability, and to deal with them in an integrated way. The ability to measure vulnerability is increasingly being seen as a key step towards effective risk reduction and the promotion of a culture of disaster resilience. In the light of increasing frequency of disasters and continuing environmental degradation, measuring vulnerability is a crucial task if science is to help support the transition to a more sustainable world [8] Kasperson et al.

\section{THEORETICAL BACKGROUND}

The vulnerability concept - theoretical and conceptual issues

Four main approaches are related to the conceptualisation and measurement of risk and its components - hazard and vulnerability. The Political Economy Approach is illustrated with the so called Pressure and Release (PAR) model [2] Blaikie at al. and [12] Wisner et al., and the related Sustainable Livelihood Framework [3] DFID. This framework presents the organizational, institutional and political methods supporting local capacity building for natural disasters risk reduction, and shows that these structures are reproduced by the actions of individuals and households. The Social - Ecological Approach underlines the necessity to put human - environmental systems in the centre of risk assessment. This approach is presented by [10] Turner et al. where the transforming abilities of the society with regards to natural circumstances are shown, as well as the effects of the changing environment on social-economic systems. The framework also stresses that the vulnerability elements - exposure and susceptibility of a certain system (individuals, communities, etc.) can be rationally understood only if we address these related approaches. The third approach is connected with Disaster Risk Management (DRM) and aims at development of an integrated interpretation of risk. The approach divides vulnerability into its component: exposure, susceptibility and societal-response capacities or lack of resilience. The approach perceives vulnerability as intrinsically dynamic and, therefore, its assessment should not be restrained only to identification of the system's shortcomings but also consider its potential feedback and intervention instruments (existing and potentially developed) for reduction of the system's vulnerability. This approach also involves the sustainable development perspective of vulnerability assessment. The approach of Climate Change Adaptation (CCA) is based on the IPCC's definition that vulnerability is a function of exposure, susceptibility and adaptive capacities [7] IPCC. This approach takes into account the rate and magnitude of climate change. Particularly, the magnitude and frequency of the potentially hazardous 
natural phenomena are included when calculating the vulnerability to climate changes. Thus, the vulnerability concept changes into a definition of risk.

The current research adopts the recently developed holistic approach for disaster risk assessment and management, and the 'MOVE' conceptual framework (figure 1).

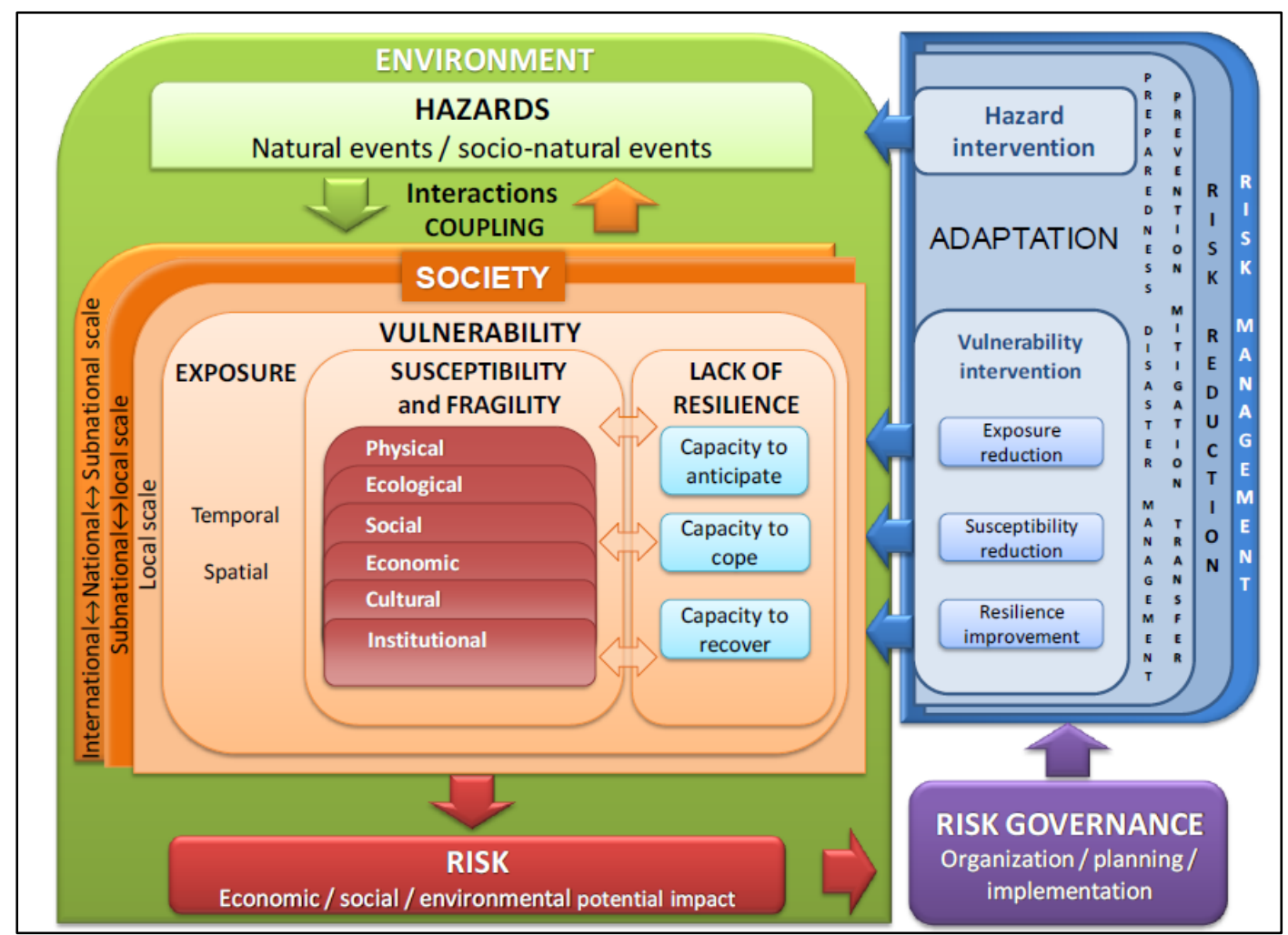

Figure 1. The 'MOVE' conceptual framework - a holistic approach to disaster risk assessment and management [4] European Commission.

This conceptual framework was developed within the 'MOVE' project (www.move$\underline{n p 7 . e u}$ ) and joins the concepts of risk and risk management ${ }^{3}$. The first concept presents risk as the result of the societies' exposure to hazards in time and space and their vulnerability. The hazards are presented as natural or socio-natural events, which are a combination of society and environment. Risk management and adaptation aim to modify the initial vulnerability conditions or hazards. Vulnerability is a combined result of the exposure, susceptibility (fragility) and resilience (capacity to anticipate, cope and recover).

$$
\text { Vulnerability }=\text { Exposure }^{4}+\text { Susceptibility }^{5}-\text { Resilience }^{6}
$$

\footnotetext{
${ }^{3}$ The term Disaster Risk management (DRM) also encompasses the concept of Disaster Risk Reduction (DRR). Thus these terms are used almost synonymously. A/N

${ }^{4}$ Exposure is defined as the predisposition of a system to be disrupted by a hazardous event due to its location in the same area of influence [5] Florina.

${ }^{5}$ Susceptibility will be defined as the elements exposed within the system, which influence the probabilities of being harmed at times of hazardous events. $\mathrm{A} / \mathrm{N}$

${ }^{6}$ The lack of resilience is another important vulnerability factor that reflects the capacity level of a society to anticipate (to intervene proactively the risk conditions), to adapt (to be prepared to face future hazardous events), as well to cope and recover effectively when such events occur. A lack of these capacities increases the vulnerability of the society. A/N
} 
Hazard and vulnerability trigger risk, which is the potential impact of the hazard occurrence on economic, social and environmental dimensions of society. The degree of risk will depend both on the susceptibility (or fragility) and the lack of resilience of the society (and of the environment, in some cases), as well as how they are related to the exposure (from local to national and international scales). In addition to the key factors which determine vulnerability, the following core vulnerability dimensions can be addressed within the comprehensive holistic assessment process:

$\checkmark$ The social dimension (component) represents the tendency of human welfare to be damaged by disruption of the individual (physical and psychological health) and collective (healthcare, education, services, etc.) social system and its characteristics (gender, marginalisation of social groups, etc.);

$\checkmark$ The economical dimension (component) represents the tendency for economic loss from destruction of physical assets and/or disruption of the production processes;

$\checkmark$ The environmental dimension (component) represents the potential for destruction of all ecological and biophysical systems and their functions. This component involves basically all ecosystem functions and services [9] Renaud.

Vulnerability assessment

In recent years, an increasing number of global and local initiatives have been launched to measure risk and vulnerability with a set of indicators and indices [1] Birkmann. In general, indicators are management tools which describe and operationalise complex system characteristics in a quantitative and transparent way. Therefore, indicator frameworks tend to bridge the gap between theoretical concepts of complex systems and decision making [6] Gallopin. This enables a comparative analysis, benchmarking and support to decision makers in complex decision situations (e.g. in crisis management and emergency planning).

\section{INTEGRATED VULNERABILITY ASSESSMENT AND MAPPING - CASE STUDY OF NORTH BULGARIA}

Indicators for the three vulnerability dimensions (Exposure, Susceptibility, and Resilience) are developed in compliance with the adopted vulnerability conceptual framework. The indicators are bound to the particular vulnerability dimensions (Social, Economic, and Environmental) (see table 1).

Table 1. Relationship between vulnerability dimensions and factors

\begin{tabular}{|c|c|c|c|c|c|c|}
\hline Vulnerability & Exposure & $\begin{array}{l}\text { Geograph- } \\
\text { ic scale }\end{array}$ & Susceptibility & $\begin{array}{l}\text { Geogra } \\
\text { phic } \\
\text { scale }\end{array}$ & Resilience & $\begin{array}{l}\text { Geograph- } \\
\text { ic scale }\end{array}$ \\
\hline \multirow[t]{4}{*}{$\begin{array}{l}\text { Social } \\
\text { Component }\end{array}$} & $\begin{array}{l}\text { Population } \\
\text { density }\end{array}$ & $\mathrm{L}, \mathrm{R}, \mathrm{N}$ & Education & $\mathrm{L}, \mathrm{R}, \mathrm{N}$ & $\begin{array}{l}\text { Transport } \\
\text { infrastructur } \\
\text { e }\end{array}$ & $\mathrm{L}, \mathrm{R}, \mathrm{N}$ \\
\hline & $\begin{array}{l}\text { Urbanized } \\
\text { territory }\end{array}$ & $\mathrm{L}, \mathrm{R}, \mathrm{N}$ & $\begin{array}{l}\text { Communicatio } \\
\mathrm{n} \text { penetration } \\
\text { rate }\end{array}$ & $\mathrm{L}, \mathrm{R}, \mathrm{N}$ & $\begin{array}{l}\text { Warning } \\
\text { system }\end{array}$ & $\mathrm{L}, \mathrm{R}, \mathrm{N}$ \\
\hline & $\begin{array}{l}\text { Population } \\
\text { structure }\end{array}$ & $\mathrm{L}, \mathrm{R}, \mathrm{N}$ & Health services & $\mathrm{L}, \mathrm{R}, \mathrm{N}$ & $\begin{array}{l}\text { Institutional } \\
\text { capacity }\end{array}$ & $\mathrm{L}, \mathrm{R}, \mathrm{N}$ \\
\hline & & $\mathrm{L}, \mathrm{R}, \mathrm{N}$ & Human health & $\mathrm{L}, \mathrm{R}, \mathrm{N}$ & $\begin{array}{l}\text { Emergency } \\
\text { service }\end{array}$ & $\mathrm{L}, \mathrm{R}, \mathrm{N}$ \\
\hline $\begin{array}{l}\text { Economic } \\
\text { component }\end{array}$ & Land use & $\mathrm{L}, \mathrm{R}, \mathrm{N}$ & $\begin{array}{l}\text { Economic } \\
\text { development }\end{array}$ & $\mathrm{L}, \mathrm{R}, \mathrm{N}$ & $\begin{array}{l}\text { Amount of } \\
\text { investment }\end{array}$ & $\mathrm{L}, \mathrm{R}, \mathrm{N}$ \\
\hline
\end{tabular}




\begin{tabular}{|l|l|l|l|l|l|l|}
\hline Vulnerability & Exposure & $\begin{array}{l}\text { Geograph- } \\
\text { ic scale }\end{array}$ & Susceptibility & $\begin{array}{l}\text { Geogra } \\
\text { phic } \\
\text { scale }\end{array}$ & Resilience & $\begin{array}{l}\text { Geograph- } \\
\text { ic scale }\end{array}$ \\
\hline $\begin{array}{l}\text { Environmenta } \\
\text { I component }\end{array}$ & $\begin{array}{l}\text { Ecosystem } \\
\text { services }\end{array}$ & L, R, N & $\begin{array}{l}\text { Protected } \\
\text { natural areas }\end{array}$ & L, R, N & $\begin{array}{l}\text { Amount of } \\
\text { investment }\end{array}$ & L, R, N \\
\hline
\end{tabular}

Key: L- Local level; R- Regional level; N- National level.

*The table is elaborated by the authors

Exposure indicators explain how social entities, such as individuals, households, organizations, communities (Social dimensions), or economic activities, i.e. industries, agriculture, etc. (Economic dimensions), or environment (Environmental dimensions) are exposed to hazardous events. Susceptibility considers the indicators which evaluate the sensitivity of an element at risk (Social system, Economic system and Environment) before and during a hazardous event. They can be evaluated through levels of preparedness, education, income, communication penetration rate, trust in institutions, etc. Resilience indicators clarify the ability of a system to persist if exposed to a perturbation by recovering during and after the hazardous event. The indicators used are warning system, evacuation routes, institutional capacity, emergency service, etc. the description of sub-indicators, as well as their connection with vulnerability are presented in table 2 .

Table 2. Description of natural disasters vulnerability indicators

\begin{tabular}{|c|c|c|c|c|}
\hline $\begin{array}{l}\text { Name of the } \\
\text { indicator }\end{array}$ & $\begin{array}{l}\text { Dimensions } \\
\text { of } \\
\text { vulnerability }\end{array}$ & Definition of sub -indicator & Units & $\begin{array}{l}\text { Functional } \\
\text { relationship with } \\
\text { vulnerability }\end{array}$ \\
\hline \multicolumn{5}{|l|}{ Exposure } \\
\hline $\begin{array}{l}\text { Population } \\
\text { density }\end{array}$ & $S$ & $\begin{array}{l}\text { Provides information on the number } \\
\text { of people per unit of area. }\end{array}$ & $\begin{array}{l}\text { people/k } \\
\mathrm{m}^{2}\end{array}$ & $\begin{array}{l}\text { Higher number of } \\
\text { people, higher } \\
\text { vulnerability }\end{array}$ \\
\hline $\begin{array}{l}\text { Urbanised } \\
\text { territory }\end{array}$ & $\mathrm{S}$ & $\begin{array}{l}\text { Relative share of the area which is } \\
\text { urbanized }\end{array}$ & $\%$ & $\begin{array}{l}\text { Higher } \% \text {, higher } \\
\text { vulnerability }\end{array}$ \\
\hline Old people & $\mathrm{S}$ & $\begin{array}{l}\text { Relative share of the population at } 65 \\
\text { years and more }\end{array}$ & $\%$ & $\begin{array}{l}\text { Higher } \% \text {, higher } \\
\text { vulnerability }\end{array}$ \\
\hline $\begin{array}{l}\text { Disabled } \\
\text { people }\end{array}$ & $\mathrm{S}$ & $\begin{array}{l}\text { Population at } 16 \text { and more years with } \\
\text { long-term reduced ability to work or } \\
\text { degree of disability (from } 50 \text { to } 90 \% \text { ) }\end{array}$ & $\%$ & $\begin{array}{l}\text { Higher \%, higher } \\
\text { vulnerability }\end{array}$ \\
\hline Land use & Ec & $\begin{array}{l}\text { Area used for industry, agriculture, } \\
\text { any types of economic activity }\end{array}$ & $\%$ & $\begin{array}{l}\text { Higher \%, higher } \\
\text { vulnerability }\end{array}$ \\
\hline $\begin{array}{l}\text { Ecosystem } \\
\text { services }\end{array}$ & En & $\begin{array}{l}\text { Total value of the assessed } \\
\text { ecosystem services, including: } \\
\text { ecological integrity, provisioning } \\
\text { services, regulating services, and } \\
\text { cultural services (B. Burkhard, F. } \\
\text { Kroll, F. Müller \& W. Windhorst et } \\
\text { al. 2009) }\end{array}$ & value & $\begin{array}{l}\text { Higher value, } \\
\text { higher } \\
\text { vulnerability }\end{array}$ \\
\hline \multicolumn{5}{|l|}{ Susceptibility } \\
\hline Education & $S$ & $\begin{array}{l}\text { Population at } 7 \text { and more years with } \\
\text { high education (high and higher) }\end{array}$ & $\%$ & $\begin{array}{l}\text { Higher } \% \text {, lower } \\
\text { vulnerability }\end{array}$ \\
\hline Hospitals & $S$ & $\begin{array}{l}\text { Number of beds in treatment hospital } \\
\text { facilities per } 10000 \text { people }\end{array}$ & number & $\begin{array}{l}\text { Higher } \% \text {, lower } \\
\text { vulnerability }\end{array}$ \\
\hline Human health & $\mathrm{S}$ & Population per 1 doctor & number & $\begin{array}{l}\text { Higher number, } \\
\text { higher } \\
\text { vulnerability }\end{array}$ \\
\hline
\end{tabular}




\begin{tabular}{|c|c|c|c|c|}
\hline $\begin{array}{l}\text { Communicatio } \\
\mathrm{n} \text { penetration } \\
\text { rate }\end{array}$ & $S$ & $\begin{array}{l}\text { Relative share of occupied dwellings } \\
\text { with Internet access }\end{array}$ & $\%$ & $\begin{array}{l}\text { Higher } \%, \text { lower } \\
\text { vulnerability }\end{array}$ \\
\hline GDP per capita & Ec & $\begin{array}{l}\text { Measures the standard of living in the } \\
\text { region and the degree of development } \\
\text { of the local economy. The higher } \\
\text { GDP per capita the region has, the } \\
\text { stronger is the local economy and the } \\
\text { better the standard of living of the } \\
\text { local population are. }\end{array}$ & value & $\begin{array}{l}\text { Higher value, } \\
\text { lower } \\
\text { vulnerability }\end{array}$ \\
\hline $\begin{array}{l}\text { Protected } \\
\text { natural areas }\end{array}$ & En & $\begin{array}{l}\text { Protected zones under Art. } 6 \text { of the } \\
\text { BDA as part of the European ecologic } \\
\text { network 'NATURA 2000' for } \\
\text { protection of types of natural habitats } \\
\text { under Council Directive 92/43/EEC } \\
\text { of } 21 \text { May } 1992 \text { on the conservation } \\
\text { of natural habitats and of wild fauna } \\
\text { and flora and for the protection of } \\
\text { wild birds habitats under Council } \\
\text { Directive } 79 / 409 / \text { EC of } 2 \text { April } \\
1979 \text { on the conservation of wild } \\
\text { birds. }\end{array}$ & $\mathrm{km}^{2}$ & $\begin{array}{l}\text { Higher } \mathrm{km}^{2} \text {, } \\
\text { higher } \\
\text { vulnerability }\end{array}$ \\
\hline $\begin{array}{l}\text { Number of } \\
\text { species }\end{array}$ & En & $\begin{array}{l}\text { Number of bird species, reported to } \\
\text { the EC for the period } 2007-2012 \\
\text { with regards to Directive } 92 / 43 / \text { EEC }\end{array}$ & number & $\begin{array}{l}\text { Higher number, } \\
\text { higher } \\
\text { vulnerability }\end{array}$ \\
\hline \multicolumn{5}{|l|}{ Resilience } \\
\hline $\begin{array}{lr}\text { Road } & \text { network } \\
\text { per } & 1000 \\
\mathrm{~km}^{2}-\mathrm{km}\end{array}$ & $S$ & $\begin{array}{l}\text { Total length of highways and roads in } \\
\text { the region. The republican road } \\
\text { network is of crucial importance for } \\
\text { the transportation of passengers and } \\
\text { loads around the country. The } \\
\text { indicator does not include streets in } \\
\text { settlements. }\end{array}$ & $\mathrm{km}$ & $\begin{array}{l}\text { Higher } \mathrm{km} \text {, lower } \\
\text { vulnerability }\end{array}$ \\
\hline $\begin{array}{l}\text { Acquired } \\
\text { tangible fixed } \\
\text { assets }\end{array}$ & Ec & $\begin{array}{l}\text { Acquired long-term direct material } \\
\text { assets by construction (after putting } \\
\text { in operation) and purchase. }\end{array}$ & value & $\begin{array}{l}\text { Higher value, } \\
\text { lower } \\
\text { vulnerability }\end{array}$ \\
\hline $\begin{array}{l}\text { Foreign direct } \\
\text { investments in } \\
\text { non-financial } \\
\text { enterprises } \\
\text { with } \\
\text { accumulation }\end{array}$ & Ec & $\begin{array}{l}\text { Investments (transactions) in long- } \\
\text { term relations and interests of foreign } \\
\text { residents (direct foreign investor) in } \\
\text { investment enterprises, established in } \\
\text { Bulgaria. }\end{array}$ & value & $\begin{array}{l}\text { Higher value, } \\
\text { lower } \\
\text { vulnerability }\end{array}$ \\
\hline $\begin{array}{l}\text { Availability of } \\
\text { the tangible } \\
\text { fixed assets } \\
\text { with ecological } \\
\text { use }\end{array}$ & En & $\begin{array}{l}\text { Expenditure on acquisition of } \\
\text { tangible and intangible fixed assets } \\
\text { with ecological use. }\end{array}$ & value & $\begin{array}{l}\text { Higher value, } \\
\text { lower } \\
\text { vulnerability }\end{array}$ \\
\hline
\end{tabular}

*The table is elaborated by the authors

**Data source: Bulgarian National Statistical Institute (www.nsi.bg)

\section{Calculation and mapping of integrated vulnerability index}

As a first step, the system of indicators presented in table 2 is transformed in comparable units by applying values 1, 2, 3, 4 or 5 depending on the category (very low, low, medium, high or very high vulnerability). Next, since indicators have different meanings for specific hazards, a hazard-specific weight has to be found and applied. Generalised 
classes of multi hazard from hydro-meteorological events are defined by the authors to be used at regional level in North Bulgaria. The set of sub-indicators are applicable at all governmental levels and the results can be compared. The weight of the vulnerability factors was calculated using the entropy method. The total weight for each separate region (municipality) for integrated exposure, susceptibility and resilience is determined according to the following formula:

Integrated Exposure $S+E c+E n /$ Susceptibility ${ }_{S+E c+E n} /$ Resilience $_{S+E c+E n}=$ $=$ Indicator $Y *$ Weight of the indicator + Indicator $Z *$ Weight of the indicator + Indicator $N *$ Weight of the indicator

(2)

The integrated vulnerability is calculated by the following correlation:

$$
V_{\text {int }}=E_{\text {int }}+S_{\text {int }}-R_{\text {int }}
$$

Thus, the calculated integrated exposure, susceptibility, resilience and vulnerability indexes are classified in five classes (Very low, Low, Medium, High and Very high) and mapped (figure 2).

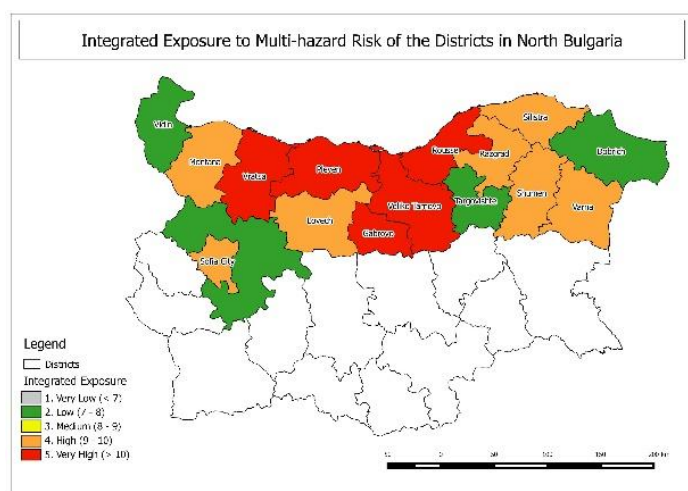

Fig. 2a

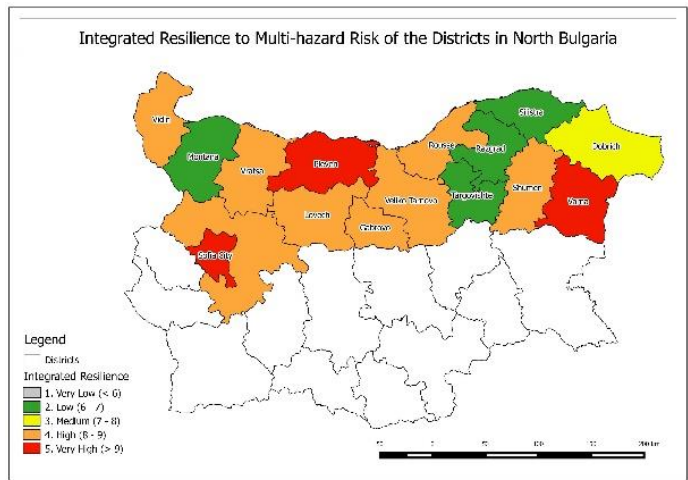

Fig. 2c

Figure 2. Integrated exposure, susceptibility, resilience and vulnerability of the administrative districts in North Bulgaria.

* The maps are elaborated by the authors. **Data source: Bulgarian National Statistical Institute (www.nsi.bg) 


\section{RESULTS AND DISCUSSIONS}

Figure 2 visualises the spatial distribution of the integrated indices of the three vulnerability factors - exposure, susceptibility and resilience for the administrative districts in North Bulgaria. The analysis of the maps shows that: the results correspond to the reality; and that the application of an integrated and multidisciplinary approach for vulnerability assessment of natural-disaster risk accounts for the physical context, the complexity and dynamics of the social and natural systems, and their interconnectedness. The holistic approach will encourage more effective risk governance and management through the development of prevention strategies to face risks and disasters. The result of the holistic approach will help to formulate the problem and to give an answer, with associated uncertainties and approximations, but taking into account the whole aspect of risk.

\section{REFERENCES:}

[1] Birkmann, J, Measuring Vulnerability to Natural Hazards - Towards DisasterResilient Societies, UNU Press, Tokyo, Japan and New York, USA, 2006.

[2] Blaikie at al., At risk: Natural hazards, People, Vulnerability and Disasters, Routledge, London, United Kingdom, 2003.

[3] DFID (Department for International Development), Sustainable Livelihood Guidance sheet (London), United Kingdom, 1999.

[4] European Commission, Research \& Innovation DG, Methods for the Improvement of Vulnerability Assessment in Europe. Assessing vulnerability to natural hazards in Europe: from principles to practice manual on concept, methodology and tools. European FP7 project 'MOVE', Belgium, 2011

[5] Florina, B, Development and Application of Flood Vulnerability Indices for Various Spatial Scales, UNESCO-IHE Institute for Water Education, Delft, the Netherlands, 2007.

[6] Gallopin, G. C., Indicators and their use: Information for Decision-making', in Moldan, Beldrich and Billharz, Suzane (eds.), Sustainability Indicators, Report of the project of indicators of Sustainable Development, New York, USA, 1997.

[7] IPCC, Climate Change: Impact, Adaptation and Vulnerability, Contribution of Warking Group tho the Fourth Assesment Report of the Intergovernmental Panel on Climate Change $=$ Cambridge University Press, Cambridge, United Kingdom, 2007.

[8] Kasperson, R. E. et al., Vulnerability to global environmental change. In The Social Contours of Risk, London: Earthscan, United Kingdom, Volume 2, pp. 245-285, 2005.

[9] Renaud, F.G., Environmental components of vulnerability. In Birkmann J.(Ed.). Measuring Vulnerability to Natural Hazards - Towards Disaster-Resilient Societies, UNU Press, Tokyo, Japan and New York, USA, 2006.

[10] Turner et al., A framework for vulnerability analysis in sustainability science. PNAS, 2003

UN-ICDR. Living with risk: a global review of disaster reduction initiatives, Belgium, 2004

[11] Wisner et al. At risk: Natural hazards, People, Vulnerability and Disasters. Routledge, London, United Kingdom and New York, USA 2004. 